\title{
Enhanced radioimmunotherapeutic efficacy of a mon- oclonal antibody cocktail against SMMC-7721 human hepatocellular carcinoma
}

\author{
SONG YI QIANG, GEN FENG WANG, XIN LAN DAI, \\ HONG XIE* \\ Shanghai Institute of Cell Biology, Chinese Academy of \\ Sciences, Shanghai 200031, China
}

\begin{abstract}
The improved tumoricidal effect of the radioantibody mixture ("cocktail") has been reported recently for the treatment of colon tumor. In the present study, we demonstrated the enhanced radioimmunotherapeutic efficacy of a monoclonal antibody (MAb) cocktail against human hepatocellular carcinoma. Therapeutic efficacy was determined by measuring the change in tumor size over a period, determining the percentage of growth inhibition of each treatment at various times after radioantibody therapy. Radioimmunotherapy of SMMC-7721 human hepatoma xenografts in athymic nude mice with combination of ${ }^{131} \mathrm{I}$ labeled Hepama-1 and ${ }^{131}$ I-labeled 9403 mouse MAbs was more effective than using either Hepeam-1 or $9403 \mathrm{MAb}$ alone. The MAb cocktail could target a greater number of hepatoma cells and increase the magnitude of hepatoma cell uptake of radioantibodies. The in vitro results explain the enhanced effect of the MAb cocktail in in vivo model system.
\end{abstract}

Key words: Mouse monoclonal antibody, human hepatocellular carcinoma, radioimmunotherapy, antibody cocktail.

* Correspondence to: Prof. Hong XIE, Shanghai Institute of Cell Biology, Chinese Academy of Sciences, 320 Yue-yang Road, Shanghai 200031, China

Tel: 8621-6431-5030 Fax: 8621-6433-1090. 
Radioimmunotherapy of MAb cocktail against human hepatoma

\section{INTRODUCTION}

In human, tumor cell populations are heterogeneous in several biochemical and biological properties. Characterization of the antigenic heterogeneity of tumor cell populations may provide an important clue that the mixture ("cocktail") of monoclonal antibodies(MAb) may be required to ensure that all the cells of a tumor could be wiped out[1]. The rationale for using MAb cocktail in tumor radioimmunotherapy has been supported by the results reported previously. An immunohistochemical study using a double-staining technique of the same tissue section indicates that a greater number of cancer cells can be detected when both anti-carcinoembryonic antigen antibodies and anti-TAG-72 antibodies are used in combination[2]. Improved radioimmunotherapy of GW-39 human colorectal cancer xenografts using the MAb cocktail against carcinoembryonic antigen and colon-specific antigen-p has also been shown[3]. In this paper, we evaluate the therapeutic efficacy of the MAb cocktail in a human hepatoma xenograft model, and demonstrate the advantage of mixing MAbs recognizing different epitopes in the treatment of human hepatocellular carcinoma.

\section{MATERIALS AND METHODS}

\section{Materials}

RPMI 1640, Gibco; fluorescein isothiocyanate (FITC), Sigma; mouse MAb isotyping kit, Sigma; sephadex-25, Sigma; SDS-PAGE high and low molecular weight markers for proteins, Sigma; goat anti-mouse IgG peroxidase conjugate, Sigma; iodogen (chloramine-1, 3, 4, 6-tetrachloro -3, 6diphenylglycoluril), Sigma; sodium ${ }^{131}$ iodine, Isotope Research Institute, Chinese Academy of the Atom Sciences. MAb Hepama-1 and 9403 were developed in this laboratory[4].

\section{Cell lines and culture}

Human hepatoma cell line SMMC-7721 was obtained from the Second Military Medical University. Hybridoma OKT3 secreting MAb OKT3 was obtained from American Type Culture Collection. Cells were cultured in RPMI 1640 medium containing 10\% new-born calf serum, in a humidified incubator at $37{ }^{\circ} \mathrm{C}$ with $5 \% \mathrm{CO}_{2}$.

\section{Purification and characterization of MAbs}

Mouse MAb Hepama-1 and 9403 bound to different antigens from SMMC-7721 human hepatoma cells were purified from ascitic fluid on DEAE-52 (Whatman) columns[4], and SDS-PAGE electrophoresis was used to determine the purity of MAbs. The final concentrations of purified MAbs were calculated by DU70 spectrophotometers (Beckman) as $52.0 \mu \mathrm{M}$ for 9403 and $27.3 \mu \mathrm{M}$ for Hepama-1. The detectable lowest concentrations of MAb 9403 and Hepama-1 by indirect immunofluorescence staining[4] were $3 \mathrm{nM}$ and $6 \mathrm{nM}$ respectively. Isotype of MAb 9403 and Hepama-1 as determined by the mouse $\mathrm{MAb}$ isotyping kit were $\operatorname{IgG}_{1}$ and $\mathrm{IgG}_{2 \mathrm{~b}}$ respectively. MAb antigenbinding saturation concentration was $0.65 \mu \mathrm{M}$ for 9403 and $1.0 \mu \mathrm{M}$ for Hepama-1 by flow cytometry (Becton-Dickinson). MAb OKT3 was used as a negative control antibody.

\section{Labeling of MAbs}

MAbs were conjugated to FITC[5], or labeled with iodine-131 ( $\left.{ }^{131} \mathrm{I}\right)$ by Iodogen method[6]. Radiochemical purity of ${ }^{131}$ I-labeled MAbs was beyond $95 \%$ within $24 \mathrm{~h}$. For radioimmunotherapy, 
specific activities of $5 \sim 7 \mu \mathrm{Ci}{ }^{131} \mathrm{I}$ per $\mu \mathrm{g}$ of protein were obtained.

\section{Competitive binding assay by flow cytometry}

Competitive binding assay was performed to determine whether MAb Hepama-a and 9403 recognized different antigenic determinats according to the method reported previously[2]. MAb 9403 was tested for its ability to compete for the binding to hepatoma cells with FITC-Hepama-1. Frist, SMMC-7721 cells were put into five different test tubes, then saturated amount of MAb 9403, Hepama-1 and OKT3 were added seperately in to each of test tubes and incubated for 45 min at $4{ }^{\circ} \mathrm{C}$, finally FITC-Hepama-1 was added seperately to these three test tubes and incubated again for $45 \mathrm{~min}$ at $4{ }^{\circ} \mathrm{C}$, the amount of bound FITC-antibody was determined as percentage of positive cells as measured by flow cytometry. OKT3 antibody was used here as control for competitive binding and the remaining two tubes with FITC-mouse IgG and FITC-Hepama-1 were served as values for blank control and control for normal FITC-Hepama-1 binding.

\section{Western blot analysis}

The total protein of SMMC-7721 cells was separated by 10\% PAGE, transferred to Hybond C nitrocellulose membrane (Amersham), and then hybridized with MAbs according to the conventional method.

\section{Human hepatoma xenograft model}

Guidelines for the Care and Use of Animals approved by the Experimental Animal House, Shanghai Institute of Cell Biology were followed. Male or female Balb/c nude mice with the average body weight of 18-22 g were used. For the radioimmunotherapy study, SMMC-7721 human hepatoma cells were incubated at $37{ }^{\circ} \mathrm{C}$ for $30 \mathrm{~min}$ with either $100 \mu \mathrm{Ci}{ }^{131} \mathrm{I}, 100 \mu \mathrm{Ci}$ of ${ }^{131} \mathrm{I}$-labeled individual antibody or a mixture of the two ${ }^{131}$ I-labeled antibodies with $50 \mu \mathrm{Ci}$ each. The cell suspension was injected subcutaneously into nude mice with $1.0 \times 10^{7}$ cells per mouse. Tumor size was determined in three dimensions by caliper measurement. There was no difference in the size of tumors between the ${ }^{131}$ I-treated and ${ }^{131}$ I-labeled antibody-treated groups on the first day. Subsequent measurements of tumor size were compared to the initial measurement, and the average change in size was recorded over a period[3]. When the experiments were ended, all animals were sacrificed by cervical dislocation.

\section{Statistics}

The statistical significance of differences $(\mathrm{P}<0.05)$ was determined using the Student's t-test

\section{RESULTS AND DISCUSSION}

As shown in Fig 1, treatment of SMMC-7721 human hepatoma xenografts with ${ }^{131}$ I-labeled Hepama-1 or 9403 MAbs resulted in an obvious growth inhibition compared with ${ }^{131}$ I-treated tumors after two weeks. But there was no statistically significant differences in tumor growth when ${ }^{131}$ I-labeled individual MAbs were administered alone. In an attempt to improve the therapeutic efficacy, the tumoricidal activity of a mixture of equal $\mu \mathrm{Ci}$ of the two MAbs was further evaluated. Fig 1 illustrated a greater tumoricidal effect of the MAb combination compared with each antibody alone after two weeks. Tab 1 summarized the percentage of growth inhibition of the MAb cocktail in comparison with that of each individual antibody. The MAb cocktail resulted in 33\% more growth inhibition than Hepama-1 ( $\mathrm{P}=0.002$ for the comparison of the mixture versus Hepama-1 alone), and $27 \%$ more growth 
Radioimmunotherapy of MAb cocktail against human hepatoma

suppression than 9403 ( $\mathrm{P}=0.005$ for the mixture versus 9403 alone).

Tab 1. Percentage of tumor growth inhibition with the treatment of ${ }^{131}$ I-labeled MAbs against SMMC-7721 human hepatoma

\begin{tabular}{lccc}
\hline Treatment & $\begin{array}{c}\text { Total number of } \\
\text { mice tested }\end{array}$ & $\begin{array}{c}\text { Tumor volumn } \\
\left(\mathrm{mm}^{3}\right)\end{array}$ & $\begin{array}{c}\text { Inhibition } \\
(\%)\end{array}$ \\
\hline${ }^{131}$ Ialone & 10 & $4710 \pm 1791$ & \\
Hepama-1 & 10 & $2750 \pm 1187$ & 41.6 \\
9403 & 11 & $2444 \pm 1071$ & 48.1 \\
Hepama-1 +9403 & 9 & $1169 \pm 596$ & 75.2 \\
\hline
\end{tabular}

The therapeutic results on day 50 post-injection of the radiolabeled MAbs were used to calculate the percentage of growth inhibition.

Fig 1. Radioimmunotherapy of SMMC7721 human heptoma xenografts in nude mice using MAb cocktail. Nude mice injected with SMMC7721 hepatoma cells were treated with either $100 \mu \mathrm{Ci}{ }^{131} \mathrm{I}, 100 / \mu \mathrm{Ci}$ of ${ }^{131}$ I-labeled individual antibody alone or $50 \mu \mathrm{Ci}$ each of the two antibodies. The size of tumors was determined by caliper measurement over time post-injection, the average at each time point was plotted.

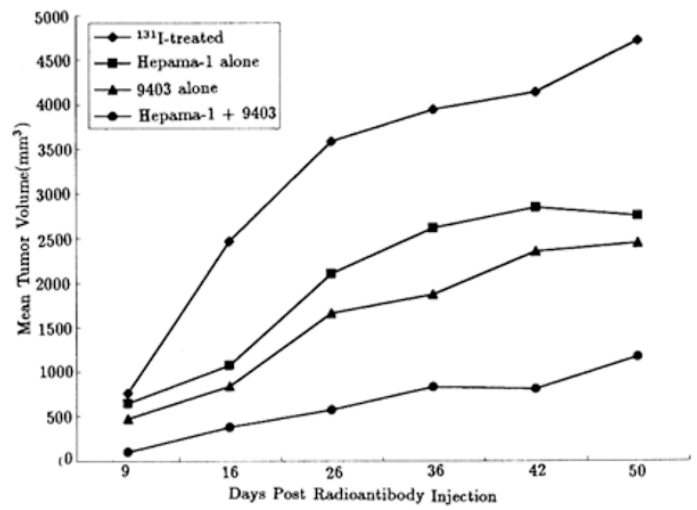

One possible explanation for the enhanced radioimmunotherapeutic efficacy of the MAb cocktail is that the mixture targets a greater number of cancer cells. If one radioantibody only binds those cells that are positive to its directed antigen, then a cocktail with other antibodies specific for other antigens or epitopes may be more beneficial than an individual antibody and may prevent the growth of those cancer cells that would otherwise escape the therapy. As shown in Tab 2, the antibodybinding amount of hepatoma cells was reflected by the percentage of positive cells measured by flow cytometry. When the hepatoma cells were incubated with 0.005 $\mu \mathrm{M} \sim 2.73 \mu \mathrm{M}$ of Hepama-1, the percentages of positive cells were about $14 \% \sim 70 \%$. However, the further increase of positive cell count could be obtained when Hepama1 of the above-mentioned concentrations was used in combination with $0.650 \mu \mathrm{M}$ (antigen-binding saturation concentration) of 9403. These results suggested that MAb cocktail could target a greater number of human hepatoma cells because they could recognize the different antigens of those cells. 
Tab 2. The percentage of hepatoma cells recognized by MAbs

\begin{tabular}{llc}
\hline Treatment & $\begin{array}{c}\text { Concentration } \\
(\mu \mathrm{M})\end{array}$ & $\begin{array}{c}\text { Positive cells } \\
(\%)\end{array}$ \\
\hline Untreated & 0 & 2.96 \\
Hepama-1 & 0.005 & 14.1 \\
Hepama-1 & 0.030 & 57.2 \\
Hepama-1 & 0.300 & 69.7 \\
Hepama-1 & 2.730 & 67.5 \\
9403 & $0.650^{\mathrm{a}}$ & 76.6 \\
Hepama-1 +9403 & $0.005+0.650$ & 79.4 \\
Hepama-1 +9403 & $0.030+0.650$ & 82.6 \\
Hepama-1 +9403 & $0.300+0.650$ & 86.5 \\
Hepama-1 +9403 & $2.730+0.650$ & 85.3 \\
\hline
\end{tabular}

Percentage of positive cells was determined by flow cytometry.

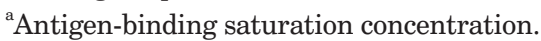

(MAb indirect immunofluorescence staining was used in the present study).

Another possible reason for the improved tumoricidal effect of the MAb cocktail is that the mixture targets more antigen epitopes on individual tumor cells. Different fluorescence intensities on individual human hepatoma cells treated with Mabs were determined by flow cytometry in vitro (Fig 2). Tumor cell uptake of $1.5 \mu \mathrm{M}$ of each antibody in combination (Fig 2 D) was $69 \%$ higher than the uptake of $1.5 \mu \mathrm{M}$ Hepama-1 alone(Fig 2 B) and 23\% higher than the uptake of $1.5 \mu \mathrm{M} 9403$ alone (Fig 2 C). This increased uptake of the MAb cocktail by hepatoma cells may be associated with recognizing distinct epitopes on tumor cells. To determine whether MAb Hepama-1 and 9403 bound the same antigen determinants, competitive binding analysis was performed using FITC-MAbs and unlabeled-MAbs.

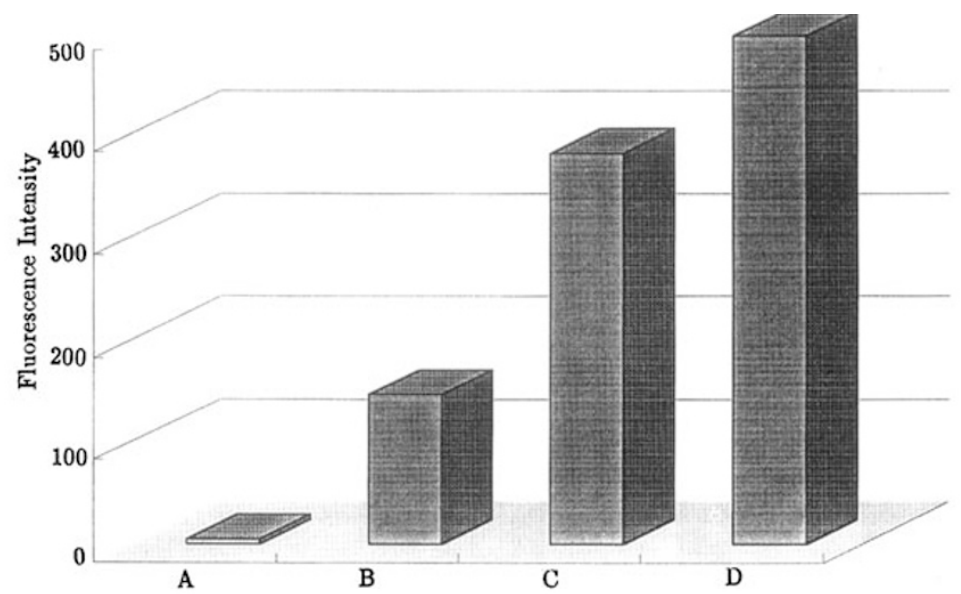

Fig 2. Fluorescence intensities on SMMC-7721 human hepatoma cells with the in vitro treatment of MAbs. MAb indirect immunofluorescence staining was used in the present study. Fluorescence intensities were determined by flow cytometry.
A : Untreated
B: Hepama-1
C: 9403
D: Hepama-1 +9403 
Radioimmunotherapy of MAb cocktail against human hepatoma

Unlabeled-Hepama-1 competed with FITC-Hepama-1, whereas unlabeled-9403 did not compete with FITC-Hepama-1 (Tab 3). It demonstrated that MAb Hepama-1 and 9403 recognized different epitopes on the human hepatoma cells. This result was further supported by Western blot analysis (Fig 3). Under the same conditions, MAb Hepama-1 was shown to be reactive with a $43 \mathrm{k}$ Da molecule (Fig $3 \mathrm{~A}$ ), but MAb 9403 gave no antigen band (Fig 3 B), further suggesting that antigenic determinants recognized by the above mentioned two MAbs are different.

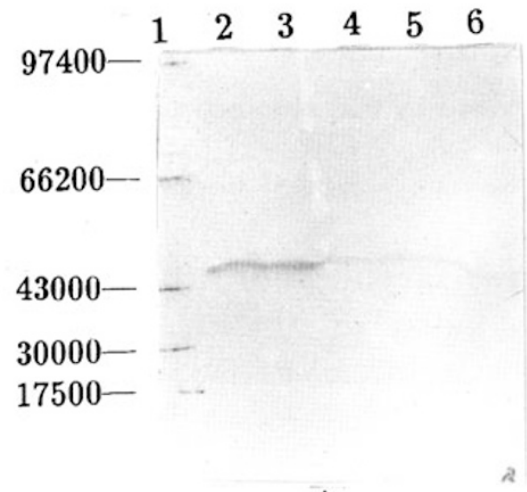

A

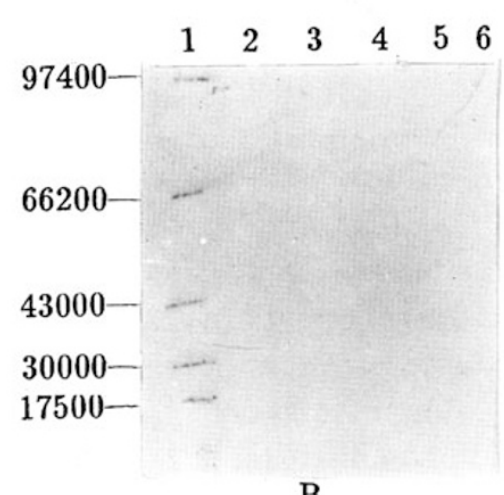

B

Fig 3. Western blot analysis of epitopes specified by MAb Hepama-1 and 9403 in SMMC-7721 cells. Lane 1: molecular marker.

Lane 2-3: total protein of SMMC-7721 cells.

Lane 4-6: protein from culture supernatant of SMMC-7721 cells.

A: hybridized with MAb Hepama-1.

B: hybridized with MAb 9403.

Protein concentration was $80 \mu \mathrm{g}$ per sample.

Tab 3. Competitive binding analysis using FITC-Hepama-1

\begin{tabular}{lc}
\hline Treatment & $\begin{array}{c}\text { positive cells } \\
(\%)\end{array}$ \\
\hline FITC-mouse IgG $(1: 20)$ & 3.3 \\
FITC-Hepama-1 $(1: 20)$ & 71.4 \\
OKT3 $(1.3 \mu \mathrm{M})+$ FITC-Hepama-1 $(1: 20)$ & 67.1 \\
Hepama-1 $(1.3 \mu \mathrm{M})$ + FITC-Hepama-1 $(1: 20)$ & 35.1 \\
$9403(1.3 \mu \mathrm{M})$ + FITC-Hepama-1 $(1: 20)$ & 62.5 \\
\hline
\end{tabular}

Percentage of positive cells was determined by flow cytometry. Nonlabeled MAbs were tested for their ability to compete for the binding to hepatoma cells with FITC-Hepama-1. For the details, see "Materials and Methods".

In summary, in view of the degree of antigenic heterogeneity which has been observed in human hepatocellular carcinoma, we have improved the radioimmunotherapy by using a MAb cocktail that targets a greater number of human hepatoma cells and different epitopes on the same cell. However, further studies are still needed to 
validate the exact mechanism of the MAb cocktail by means of direct microscopical observation of individual MAbs conjugated to different fluorescins.

\section{ACKNOWLEDGEMENT}

This work was supported by National (863) High Technology Development Program. Special thanks are due to Dr. Xing-Wang WANG for his cordial help.

\section{REFERENCES}

[1] Marx JL. Monoclonal antibodies in cancer. Science 1982; 216(16):283-5.

[2] Ohuchi N, Simpson JF, Colcher D, et al. Complementation of anti-CEA and anti-TAG-72 monoclonal antibodies in reactivity to human gastric adenocarcinomas. Int $\mathrm{J}$ Cancer 1987; 40:726-33.

[3] Blumenthal RD, Kashi R, Stenphens R, et al. Improved radioimmunotherapy of colorectal cancer xenografts using antibody mixtures against carcinoembryonic antigen and colon-specific antigen-p. Cancer Immunol Immunother 1991; 32(5):303-10.

[4] Xie H, Yang ZH, Chen RM, et al. Two mouse hybridomas secreting monoclonal antibodies against human liver carcinoma and their antibody specificity. Acta Biol Exp Sin 1985; 18(2):263-70.

[5] Hijmans W, Schuit HRE, Klein F. An immunofluorescence procedure for the detection of intracellular, immunoglobulins. Clin Exp Immunol 1969; 4(4):457-72.

[6] Fan Z, Tang ZY, Zhong GR, et al. Evaluation of iodogen and chloramine T methods in large dose radioiodination of human hepatoma ferritin antibody for radioimmunoscintigraphy and radioimmunotherapy. Acta Acad Med Shanghai 1992; 19(2):158-60.

Received June-5-1998. ～Revised July-27-1998. ～Accepted July-31-1998. 